University of St. Thomas, Minnesota

UST Research Online

2013

\title{
Tenacity: The American Pursuit of Corporate Responsibility
}

Kenneth E. Goodpaster

University of St. Thomas, Minnesota, kegoodpaster@stthomas.edu

Follow this and additional works at: https://ir.stthomas.edu/ocbeblpub

Part of the Business Law, Public Responsibility, and Ethics Commons

This Article is brought to you for free and open access by the Ethics and Business Law at UST Research Online. It has been accepted for inclusion in Ethics and Business Law Faculty Publications by an authorized administrator of UST Research Online. For more information, please contact asle4660@stthomas.edu. 


\title{
Tenacity: The American Pursuit of Corporate Responsibility
}

\author{
KENNETH E. GOODPASTER
}

\begin{abstract}
This article attempts to answer the question, "What are the most important ideas from serving as Executive Editor of the five-year history project that culminated in the book, Corporate Responsibility: The American Experience?" The ideas focus on (1) clarifying the phenomenon of tenacity; (2) looking at three foundations of our tenacity; and (3) asking "How fragile is our tenacity?" This article also presents three foundational principles that underlie the American experience of corporate responsibility. First, the Checks \& Balances Principle tells us that there are checks and balances in democratic capitalism which give us confidence that the pursuit of economic goals will be moderated for the common good. Second, the Moral Projection Principle shows that there is good reason to consider the corporation not only as a legal person under corporate law but also as a moral person. And, last, the Moral Common Ground Principle reflects that there are shared moral values ascertainable by well-developed consciences in individuals and in corporations. The article concludes with this argument: The tenacity regarding corporate responsibility that has been so characteristic of American capitalism is fragile-calling for serious vigilance if it is to endure.
\end{abstract}

Kenneth E. Goodpaster is Professor and Holder of the Koch Endowed Chair in Business Ethics, Opus College of Business, University of St. Thomas, Minnesota. In February, 2013, he was the Verizon Visiting Professor in Business Ethics, Bentley University, Waltham, MA. E-mail: kegoodpaster@stthomas.edu. 
This article takes its inspiration from a five-year project on the history of corporate responsibility in the United States that I was privileged to lead as Executive Editor. My distinguished colleagues and the principal authors of this history were Professor Archie Carroll of the University of Georgia, Professor Kenneth Lipartito of Florida International University, Professor James Post of Boston University, and Professor Patricia Werhane of the University of Virginia and DePaul University. This work was recently published by Cambridge University Press under the title Corporate Responsibility: The American Experience. I should also mention that this project was made possible by a generous grant to the University of St. Thomas from the Halloran Philanthropies in Philadelphia, Pennsylvania $^{1}$ (see Figure 1).

What this history project offered to all of us who participated in it was a degree of perspective on the subject of corporate responsibility that I doubt any of us could have claimed at the outset of the work. ${ }^{2}$ I have been asked on numerous occasions, "What's the most important idea-your biggest 'take-away'-from

FIGURE 1 Cover of Corporate Responsibility: The American Experience.

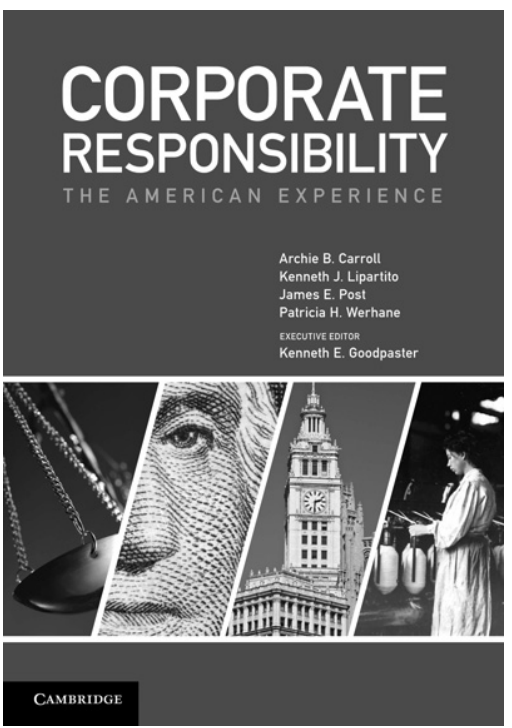


the five years of work that went into this history?" This article represents my attempt to answer that question.

I will be arguing for three propositions:

- First, the most striking characteristic of American culture, from the time the modern corporation arrived on the scene in the nineteenth century through the first decade of the twenty-first century, has been the tenacity with which we have held to a free enterprise market economy despite frequent disappointments.

- Second, this tenacity reveals several basic convictions about business ethics in America. These convictions encompass (a) our confidence in checks \& balances for sustaining our ideals as a society; (b) our view of the corporation not only as a legal person under constitutional law but also as a moral person; and (c) a set of shared moral convictions about right and wrong, good and bad, virtue and vice.

- My third proposition is that going forward, our American tenacity about corporate responsibility is fragile-because the convictions that have given it strength in the past may or may not be able to support it in the future. If we lose confidence in our institutional systems and/or in our shared moral convictions, the discipline and practice of business ethics as we currently understand it will weaken and wane.

\section{CLARIFYING THE PHENOMENON OF TENACITY}

During the past two centuries, corporations have demonstrated amazing productivity, innovation, and adaptability-and when they have displayed questionable ethical or social behavior, our persistent response as Americans has been to improve them, either internally or externally, rather than to overturn the system in favor of more socialistic models. Despite challenges to corporate legitimacy, Americans have sought to deepen corporate responsibility. ${ }^{3}$

Think about it for a moment: "Corporate responsibility" in the American experience is a reality that has a history! The fact that our history project has a subject matter is a nontrivial comment on American society that we tend to take for granted. We can joke-as we often do-about "business ethics" being an oxymoron, 
but what if it really was an oxymoron? What if the attribution of adjectives like "responsible" or "ethical" to corporations was pointless, ridiculous, even self-contradictory? The very idea of insisting that business organizations (already considered legal persons) must be ethical, or responsible actors would be meaningless unless they had some degree of discretion or liberty.

But the idea is not meaningless. It is embedded in our law and in our everyday discourse about leadership and corporate culture. I will say more about the legal system later, but it is worth pointing out here, as we do in the history volume just published, that we attribute personhood to corporations under American law and in our common moral discourse:

US law treats corporations as legal persons and tends to hold corporations themselves, and not merely the managers and employees who make up the corporation, accountable. In fact, we refer to companies as if they are individual entities, and we speak of corporate responsibility as if it applied to a single entity, even though we cannot actually shake hands with companies or lock them up. If corporations are legal persons, and thus artificial entities, this makes sense. ${ }^{4}$

Of course the American experience with corporate responsibility reveals both "good news" and "bad news" about business organizations.

\section{The Good News}

Throughout the history of corporate responsibility in America, there has been praise for the contributions of business organizations for many reasons, including the following:

- innovation in manufacturing and technology

- the provision of employment opportunities

- increased productivity

- contributions to the overall health and longevity of American lives

- improved economic opportunities for minorities and women

- general contributions to the public sector through tax revenues

- philanthropic generosity to social institutions, educational institutions, and the arts 


\section{The Not-So-Good News}

Across those same pages of American history, there have been serious negative charges leveled at the corporation, at corporate behavior, and at business as an institution. Some of the prominent criticisms have been as follows:

- abuse of power by monopolies

- violence toward, and exploitation of, labor on the part of management

- employee "captivity" in company towns

- unsafe labor practices (including child labor)

- discrimination against minorities and women in the workplace

- indifference to consumer product safety

- unresponsiveness to the importance of the natural environment

- financial manipulation and breaches of fiduciary obligations to investors

- betrayal of American workers (and exploitation of foreign workers) in the pursuit of globalization

Instead of surrendering the business system (the private sector) by centralizing economic decision making in the public sector, Americans have relied upon checks and balances between and among the public sector, the private sector, and a "third sector" that has been called by various names: the "social-cultural sector," "the moral-cultural sector," sector," ${ }^{8}$ or simply "private associations."

During the nineteenth century, Karl Marx and other critics of capitalism saw it as essentially morally bankrupt, relentlessly alienating in its exploitation of workers. Indeed, between the midnineteenth century and the mid-twentieth century, competing economic systems were clearly gaining energy in both Europe and Asia. However, American companies, the American public, and the U.S. government responded to this critique with voluntary initiatives designed to "humanize" free enterprise-or with involuntary boundaries when voluntarism was unreliable or prevented by competitive dilemmas. So far, this American pursuit of corporate responsibility seems to have succeeded-or at least most forms of collectivism seem to have failed. 
It is as if the American disdain for political centralization, so evident in its rejection of monarchy, generated a corresponding disdain for economic centralization in its affirmation of free market business organizations.

Again and again, we have witnessed this pattern: appeals by citizens and civic associations in the public square for business leadership and accountability-and failing this-appeals in legislatures and courtrooms for curbs on business behavior and punishment for past wrongdoing. We presume that the corporation, despite its preoccupations with efficiency, profitability, and competitiveness, and despite its need to comply with governmental imperatives, can and should be responsive to individual rights and to the common good. We presume, in other words, that the corporation can and must develop an ethical response system, not just an economic and a legal response system. Now let us turn to my second main proposition and the basic foundations that lie behind the tenacity of our pursuit of corporate responsibility.

\section{THREE FOUNDATIONS OF OUR TENACITY}

Three foundational convictions underlie what I am calling American tenacity regarding corporate responsibility:

1. The Checks \& Balances Principle. There are checks and balances in democratic capitalism which give us confidence that the pursuit of economic goals will be moderated with attention to the common good.

2. The Moral Projection Principle. There is good reason to consider the corporation not only as a legal person under constitutional law but also as a moral person.

3. The Moral Common Ground Principle. There are shared moral values ascertainable by well-developed consciences in individuals and in corporations.

Most Americans understand the idea of a political set of checks and balances, that is, the separation of governmental powers among legislative, executive, and judicial branches to avoid too much concentration of power in any branch. However, when I refer to the "Checks \& Balances Principle," I have a related, but larger scale idea in mind. 


\section{The First Underlying Conviction}

The first foundational conviction has already been alluded to, namely, that Americans have placed a good deal of confidence in the social arrangements that sustain our core ideals. This "Checks \& Balances Principle" was born alongside our Declaration of Independence and our constitutional rejection of monarchy.

In the nineteenth century, Alexis de Tocqueville remarked about Americans' confidence in and reliance upon not only government and commerce but also "private associations" to achieve social stability. ${ }^{10}$ In the twentieth century, Michael Novak, in his book, The Spirit of Democratic Capitalism, echoed de Tocqueville when he offered a description of American society as an intersection of three broad subsystems or "sectors": the economic, the political, and the moral-cultural (see Figure 2 below). In Novak's words,

Democratic capitalism is not a "free enterprise system" alone. It cannot thrive apart from the moral culture that nourishes the virtues and values on which its existence depends. It cannot thrive apart from a democratic polity committed, on

FIGURE 2 An Interpretation of Novak's Tripartite View of Society.

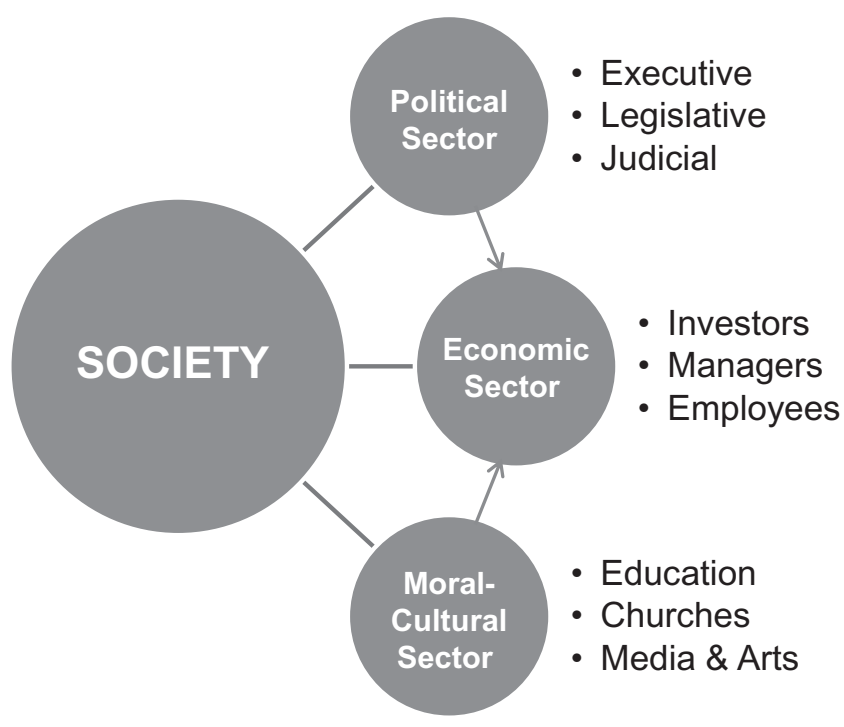


the one hand, to limited government and, on the other hand, to many legitimate activities without which a prosperous economy is impossible. ${ }^{11}$

The economic sector accounts largely for the wealth of a nation (its production of goods and services). In keeping with the Preamble to the United States Constitution, the political sector aims to "establish Justice, insure domestic Tranquility, provide for the common defense, promote the general Welfare, and secure the Blessings of Liberty to ourselves and our Posterity." The moralcultural sector shapes and articulates our moral values through the basic elements of civil society, including the family, educational institutions, churches, the media (print and electronic), and various other nonprofit associations.

The important point is that business organizations, as elements of the economic sector of our society, do not function in a vacuum. They function in an atmosphere of "practical wisdom" supplied by the other two sectors: by the political sector through legal statutes, regulations, and court decisions; and by the moral-cultural sector through appeals by various stakeholder groups, by the business press, by churches, and increasingly by social media and the Internet. ${ }^{12}$ As Novak points out, "At various times in American history, both the political system and the moral-cultural system have seriously intervened, positively and negatively, in the economic system. Each of the three systems has modified the others." 13

We have pursued corporate responsibility through actions in the public square-identifying problems, appealing for solutions to business leadership, enlisting political leadership, and even showing leadership in the "third sector"-churches, business schools, advocacy groups, other nongovernmental organizations, and the media. The consistent American aspiration, in other words, has been the moral improvement of the business corporation:

- from condemnations of child labor in 1832 to the Fair Labor Standards Act in 1938

- from the Seneca Falls Declaration of 1848 to the Women's Rights Movement of the 1960s

- from the Emancipation Proclamation in 1862 to the Civil Rights Act in 1964 
- from the protests leading up to the Sherman Antitrust Act in 1890 to Theodore Roosevelt's energetic application of it in the first decade of the twentieth century ${ }^{14}$ (see Figure 3 below)

These transformations have evolved (sometimes all too slowly) over time from interactions among corporations, the government, and various institutions representing the moral and cultural values of the American public. Critics of the abuses and misfortunes of capitalism have often appealed to the public sector for control and redress but usually as a last resort. Long before legislative, judicial, or executive governmental interventions, Americans organized associations and appealed to whoever would listen when the lives and livelihoods of employees, consumers, communities, and the natural environment were at stake. Corporations often did listen, and often sought to devise their own creative solutions to the social problems of capitalism.

FIGURE 3 "Concerning a Growing Menace," chromolithograph by Joseph Keppler, Puck, September 30, 1903. Courtesy of the Library of Congress, Prints and Photographs Division. ${ }^{15}$

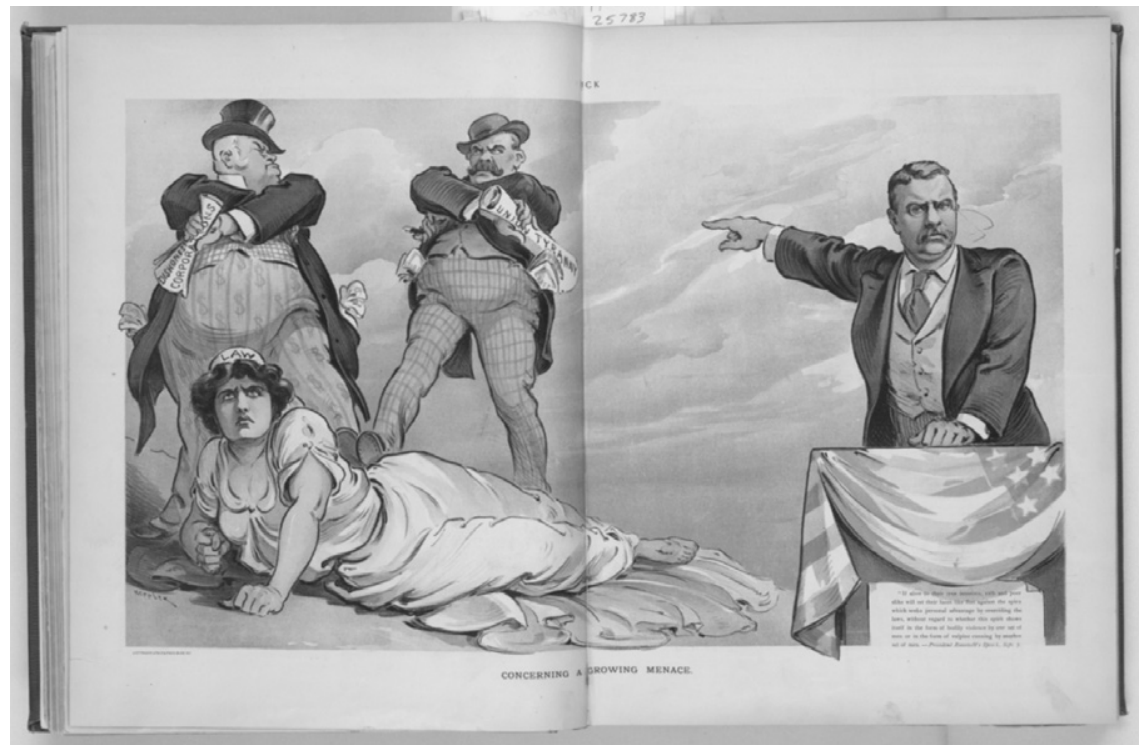


This Checks \& Balances architecture means that each sector must coexist in equilibrium with two other societal influences-a kind of social ecosystem. Each sector must check and be balanced by the other two. Applying this to business institutions, the resilience of American capitalism has been encouraged by pressures to respond to both political and moral-cultural stimuli. ${ }^{16}$

As our history has repeatedly illustrated, the press, labor unions, churches, associations of minorities and women, and groups of citizens dedicated to truth in advertising have been the voices of the moral-cultural sector directed at business practices when they were found wanting. When these voices have not been heeded, they have formed coalitions with the political sector to influence business behavior.

\section{The Second Underlying Conviction}

The second foundational conviction that underlies our tenacity about corporate responsibility-The Moral Projection Principleacknowledges the "checks \& balances" idea just described, but sees it as insufficient because it is too external. The evolution of the American corporation has led us in the direction of trying to internalize and institutionalize responsibility rather than depend solely on political and moral-cultural external pressures.

Over the past two centuries, our society has become what Peter Drucker referred to as a "society of organizations." ${ }^{17}$ Personal actors on the economic, political, and moral-cultural stage have more and more been replaced by institutional or organizational actors. ${ }^{18}$ If we combine with the evolution of our "society of organizations" the fact alluded to earlier, that, by 1868 corporations were firmly established under American law as "legal persons," it should not be surprising to find that corporations were eventually expected to behave in society with consciences analogous to individual persons ${ }^{19}$ (see Figure 4).

In truth, the idea of the corporation as a legal person was established long before the Fourteenth Amendment to the U.S. Constitution in 1868. It was articulated as early as 1819 when the Supreme Court ruled that the Trustees of Dartmouth College could act as a corporate body "to have, get, acquire, purchase, receive, hold, possess and enjoy. . ." properties and to "accept and 
FIGURE 4 The Principle of Moral Projection: Personal Consciences and Subgroups Influence Organizational or Corporate Conscience.

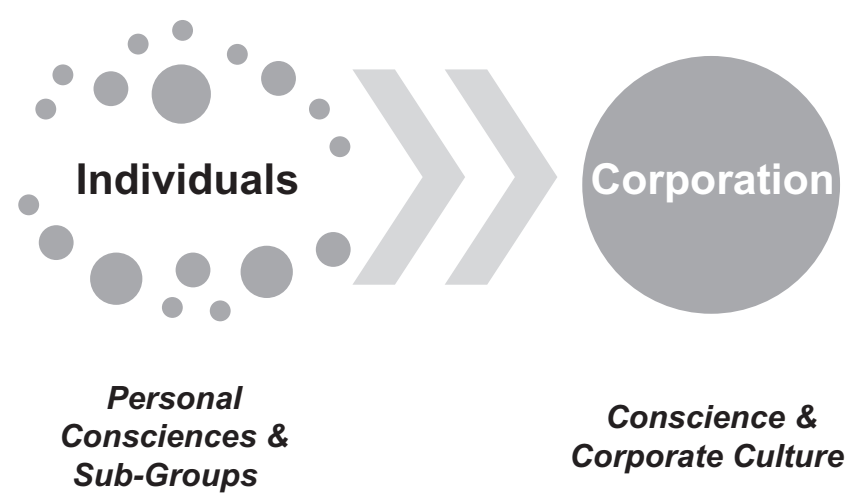

receive any rents, profits, annuities, gifts, legacies, donations or bequests. . ." for their use. ${ }^{20}$

However, it is important to add that the "legal personhood" of the corporation is not the same as its moral personhood. Moral personhood requires that the corporation have sufficient discretion or freedom under the law so that the ideas of responsibility and conscience can make sense. Without such freedom, corporate leaders and managers might simply be constrained by law to make decisions solely on the basis of nonmoral considerations such as profit maximization. ${ }^{21}$ Only an organization that is relatively free can be asked to be responsible; an organization that is merely an arm of the state can only be compliant. ${ }^{22}$ As corporate law scholar Lyman Johnson pointed out to our research team,

It is . . . the very discretion afforded by law that makes discussions of corporate responsibility possible and meaningful. Without such discretion-as, for example, if managers really were legally required to maximize profits-advocacy of socially responsible behavior would truly be academic because managers would be prohibited from engaging in such conduct. ${ }^{23}$

In 1982, John Matthews and I formalized this analogical perspective in an article in the Harvard Business Review, called "Can a 
Corporation Have a Conscience?" and labeled it the "Principle of Moral Projection":

It is appropriate not only to describe organizations (and their characteristics) by analogy with individuals, it is also appropriate normatively to look for and to foster moral attributes in organizations by analogy with those we look for and foster in individuals.

Indeed, the idea that Americans seek to "institutionalize" the values that we hold dear has been discussed with sophistication by a number of twentieth-century scholars. ${ }^{24}$ I should emphasize a very important fact, however, related to the Moral Projection Principle, namely that it depends for its reality on corporate leadership. The shapers and architects of the conscience of the corporation are those who lead the organization. For this reason, business ethics and the study of organizational leadership are, and should be, inextricably linked.

To recap, I have been arguing so far that Americans have displayed, over the 200-year history of capitalism in the United States, significant tenacity regarding the possibility that corporations not only can be held responsible (by the law and by the moral-cultural sector) but can also be responsible by analogy with individual persons with consciences. As part of the economic sector, corporations are not only checked and balanced from the outside by two other sectors (the moral-cultural sector and the government), they are also expected to be influenced from the inside by a kind of moral compass-a corporate conscience. American tenacity regarding corporate responsibility has been reinforced and bolstered by (1) the social architecture surrounding the corporation, and (2) the way the corporation has evolved under American law, leading us to try to institutionalize corporate responsibility in the economic sector rather than to depend solely on political and moral-cultural external pressures. Let us now turn to the third foundational conviction behind our tenacity.

\section{The Third Underlying Conviction}

The third basic conviction that underlies American tenacity about corporate responsibility-The Moral Common Ground Principle-is that whatever our differences in this pluralistic 
society, we share a significant number of moral convictions about right and wrong, good and bad, virtue and vice. We depend upon moral common ground when we appeal to individuals and to corporations to act according to their consciences. We assume moral common ground when we ask corporations to develop ethical response systems beyond their economic and legal response systems.

It may be worth pointing out that according to the Oxford English Dictionary, conscience was originally understood as a common quality which individuals shared: "a man or a people had more or less conscience," as persons or groups had more or less science, knowledge, intelligence, prudence, and so on. The word came gradually to be used as a more personal faculty or attribute so that "my conscience" and "your conscience" were understood no longer as "our respective shares or amounts of the common quality conscience," but as "two distinct individual consciences, mine and yours." ${ }^{25}$ Not long ago, New York Times columnist David Brooks echoed this perspective as he commented on a study of the ethical attitudes of young adults in universities across America:

In most times and in most places, the group was seen to be the essential moral unit. A shared religion defined rules and practices. Cultures structured people's imaginations and imposed moral disciplines. But now more people are led to assume that the free-floating individual is the essential moral unit. Morality was once revealed, inherited and shared, but now it's thought of as something that emerges in the privacy of your own heart. ${ }^{26}$

A moment's reflection on the good news and the not-so-good news that I mentioned earlier should help us to appreciate that, regarding business, Americans have historically shared and continue to share significant moral common ground:

- We cannot praise innovation, employment, productivity, philanthropy, educational opportunity, or paying taxes unless we have a shared idea of what constitutes a good life within a good community.

- Nor can we protest or condemn abuses of power, exploitation of labor, unsafe labor practices, discrimination against 
minorities and women, indifference to consumer safety, environmental pollution, or breaches of financial trust unless we have certain shared values about right and wrong, human dignity, and the common good.

In other words, our confidence that corporations can meaningfully be said to have consciences includes the conviction that our moral values are not entirely isolated from one another, and that they can be relied upon in debates about the behavior of our most important institutions-economic, political, and moral-cultural. We cannot be tenacious about our belief in corporate responsibility without a conviction that the idea of "responsibility" is not empty or fragmented. We cannot be tenacious about corporate responsibility unless we share a conviction that in the realm of goods and services, there are some goods that are truly good and some services that truly serve ${ }^{27}$ (see Figure 5).

In the Declaration of Independence, Thomas Jefferson listed the abuses of the King of Great Britain, but only after stating,

We hold these truths to be self-evident, that all men are created equal, that they are endowed by their Creator with certain unalienable Rights, that among these are Life, Liberty and the pursuit of Happiness.

To galvanize a people into life-risking action, the language of the Declaration of Independence needed to appeal to moral common ground or it would have been ineffective. In the context of corporate responsibility, the "self-evident"-or at least "widely accepted"-truths relate to the interests and rights of employees, customers, suppliers, and local communities; to fiduciary duties to investors and sustainability obligations to the natural environment; and to the critical importance of integrity in leadership and an ethical culture in organizations.

As we look across our American history of corporate responsibility, we see a pattern of speaking sometimes softly and sometimes loudly to business leaders, asking them to live up to the social contract ${ }^{28}$ internally-from the inside out-while at the same time assembling a formidable external array of controls outside and around the corporation. Compliance with laws and regulations has always been essential as a safeguard when 
FIGURE 5 Despite Differences in a Pluralistic Society, There Is Moral Common Ground.

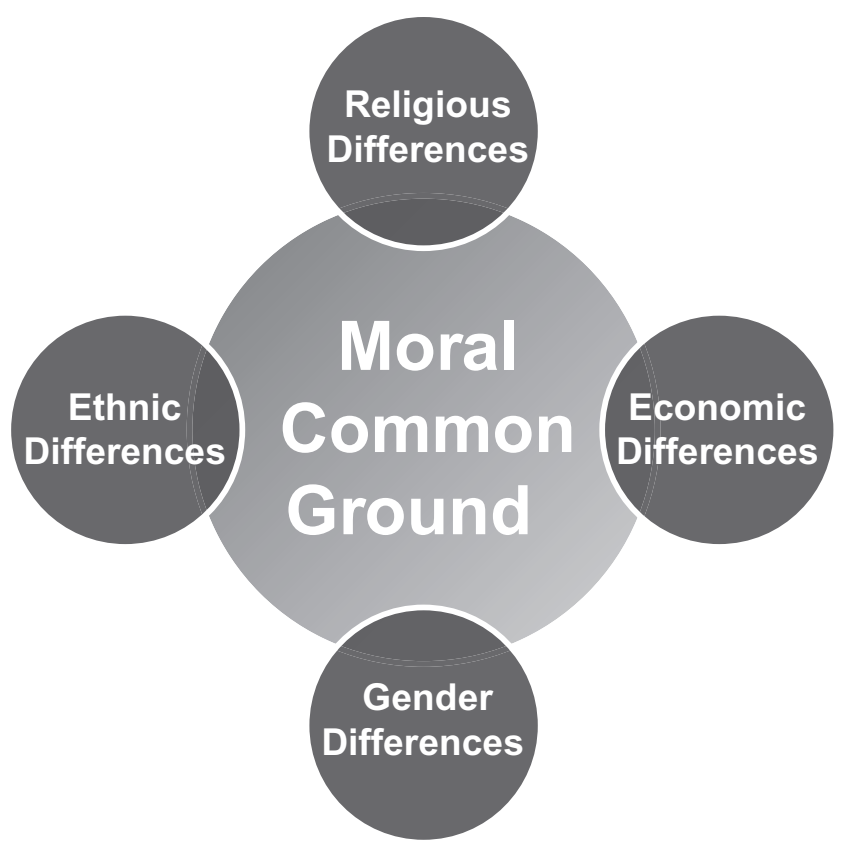

responsible business conduct has not been forthcoming (due either to moral indifference or to economic pressures).

It is perhaps worth mentioning that this approach of "internal appeals backed up by external controls" is the same strategy we employ (as parents and as educators) in dealing with individuals in our society. The conviction that conscience is possible (both personally and institutionally) does not mean that we are naive about its failures. It simply means that we must be prepared to contain those failures as we seek new ways to cultivate ethical self-regulation.

To say that there has been "moral common ground" during the history of corporate responsibility is not, of course, to imply that this common ground was self-evident from the outset. Frequently, through give-and-take in the public square, we have witnessed something akin to institutional learning: the movement from an 
unacceptable social situation to what seemed like a good solution but with unintended (and unacceptable) consequences that called for readjustment. Aristotle described this pattern as the (sometimes elusive) pursuit and discovery of a virtuous "golden mean" between two extremes. For example,

- In the nineteenth century, we moved from frequent worker destitution and homelessness to the innovation of company towns, with the unintended consequence of lost civic autonomy and independence, and have since learned to lessen workers' dependency on the corporation.

- In the wake of World War II, we grew from economic depression and material sacrifice to corporate innovation in goods and services, leading to prosperity and consumerism, but also to a culture of consumption. We are now attending to the need for sustainable economic growth.

- We moved in the mid-twentieth century from an absence of credit to the innovations associated with the liberal credit/debt policies of modern banking, with the unintended consequences of unrestrained credit, systemic risk, and eventually a loss of trust in financial institutions, and we are now seeking to discern the appropriate use of credit/debt.

- Our innovative business system has led us from timeconsuming transportation using horses and wagons to railroads and eventually to automobiles, aircraft, and space technology, with unintended consequences relating to safety and pollution, and we now are reflecting upon the true costs and true benefits of all forms of transportation.

- That same innovative business system has led us from slow communication by "pony express" and telegraph to a high tech Internet revolution, with its unintended side effects of too much information (and misinformation), and we are now examining ways to protect our privacy against identity theft and our communication systems against cyber threats.

In each of these cases, our moral common ground was clarified slowly and incrementally by discerning conditions that were unacceptable in one direction, noticing that we were replacing them with conditions that were unacceptable in the opposite direction, and finally searching for more balanced approaches. ${ }^{29}$ 
During the twentieth century, the Moral Common Ground Principle led to the gradual emergence of "stakeholder thinking" to supplement "stockholder thinking." A strong theme across our history has been the trend toward enlarging the set of parties to whom the corporation must be accountable, from providers of capital (stockholders) to other stakeholders (employees, consumers, suppliers, the communities to which the corporation belongs, and eventually the natural environment) whose claims increasingly seek and achieve a kind of parity with stockholder claims. ${ }^{30}$

Summing up, the distinctive characteristic of the American experience in the history of corporate responsibility is the tenacity with which Americans have held on to an institutional aspiration (parallel to a personal aspiration) to uphold freedom in the face of frequent failure. ${ }^{31}$ Beneath this tenacity, we have identified three foundational convictions:

1. The Checks \& Balances Principle: There are societal checks and balances in democratic capitalism which give us confidence that the pursuit of economic goals will be moderated for the common good.

2. The Moral Projection Principle: We should consider the corporation not only as a legal person under corporate law but also appeal to it as a moral person.

3. The Moral Common Ground Principle: There are shared moral values ascertainable by individuals and by corporations, and that despite economic abuses of human rights and the common good, corporations can discern goods that are truly good and services that truly serve.

The first is about our social system; the second is about organizations within the system; and the third is about our capacities to know right from wrong, good from bad, virtue from vice.

\section{HOW FRAGILE IS TENACITY GOING FORWARD?}

Our American tenacity about corporate responsibility is fragile because the foundational convictions that have given it strength in the past may or may not be able to support it in the future. 
If we lose confidence in any or all of the three convictions that I have been calling foundational-in our institutional checks and balances, in our belief that corporations can internalize ethical values, or in the moral common ground that we have been able to rely upon in the past-the discipline and practice of business ethics as we currently understand it will be unable to sustain itself for lack of a subject matter.

Whatever the future brings, we know that certain factors will continue to evolve: globalization, economic development, information technology, and corporate law. The influence of these factors on the prospects of corporate responsibility might take unpredictable forms. However, despite such uncertainties, can we say anything about the prospects for the tenacity described in this article? Well, there are negative signs on the horizon and there are positive signs.

\section{The Not-So-Good News}

On the negative side, we can discern several reasons for a loss of confidence and consequently a loosening of our tenacity:

- First, of course, is the behavior of business during the first decade of our new century, by the Enron debacle and the long list of scandals that followed it (from Arthur Andersen to WorldCom to Tyco, and so on; from Ponzi schemes to the mortgage crisis and the collapse or near collapse of financial institutions on Wall Street). In the face of these scandals, it should come as no surprise that the public has been questioning the capacity of corporations to self-regulate-to be responsible. It is also no surprise to see sweeping federal legislation like the Sarbanes-Oxley Act and the Dodd-Frank Act as political responses to these failures of our economic institutions. Apparently, the institutionalization of ethical values that has given us confidence in the past is not clearly something we can rely upon in the future. On this subject, of course, future leadership will be critical.

As a signal about the future of corporate responsibility and our tenacity in holding on to it, these events are discouraging as they inevitably lead to intensified regulation that can 
threaten the Checks \& Balances Principle as well as the Moral Projection Principle. ${ }^{32}$

- Another reason for a loss of confidence is more diffuse but no less real, namely, that cultural trends in our society signal a new level of moral relativism. Sometimes, this relativism sails under the banner of "postmodernism"; the view that "Objectivity is a myth; there is no Truth, no Right Way to read nature or a text. All interpretations are equally valid. Values are socially subjective products. Culturally, therefore, no group's values have special standing." 33 Such a view, however widespread it might be, inevitably leads us to question the "moral common ground" that has guided our pursuit of corporate responsibility in the past. In the study of American university students mentioned earlier, David Brooks comments:

- The default position, which most [students] came back to again and again, is that moral choices are just a matter of individual taste. "It's personal," the respondents typically said. "It's up to the individual. Who am I to say?"

- Rejecting blind deference to authority, many of the young people have gone off to the other extreme: "I would do what I thought made me happy or how I felt. I have no other way of knowing what to do but how I internally feel."

- Many were quick to talk about their moral feelings but hesitant to link these feelings to any broader thinking about a shared moral framework or obligation. As one put it, "I mean, I guess what makes something right is how I feel about it. But different people feel different ways, so I couldn't speak on behalf of anyone else as to what's right and wrong."

As a signal about the future of corporate responsibility, these findings suggest a weakening of the Moral Common Ground Principle. They suggest that future business leaders (and future stakeholders in business behavior) will not be able to give shared meaning to the idea of responsibility, much less corporate responsibility. With such a moral-cultural breakdown (which could undermine the Checks \& Balances Principle), it is difficult to imagine our expectations of the corporation (the Moral Projection Principle) going much beyond regulatory and judicial compliance. 


\section{The Good News}

On the positive side, we can discern several reasons for hopehope that our past and present tenacity will continue to be vindicated in the century ahead:

- During the past two decades, we have seen new emphasis on the ethical and cultural dimensions of corporate governancethe Federal Sentencing Guidelines for Organizations and the rise of the Ethics and Compliance Officer as a new profession. ${ }^{34}$ The importance of this development lies in its reinforcement of both the Checks \& Balances Principle and the Moral Projection Principle, a new form of regulation that makes use of the internalization of ethical response systems by the corporation.

- During the past decade, we have seen the emergence of the MBA Oath (analogous to the Hippocratic Oath) ${ }^{35}$ along with a new emphasis on management as a profession (something that our history of corporate responsibility recounts as born a century ago). ${ }^{36}$ Indeed, a number of authors have gone further in referring to management as a "calling" and as a "vocation." This development encourages us to believe that the ideal of corporate responsibility is alive and well within the next generation of business students and business leaders, supporting the Moral Projection Principle.

- The emerging phenomena of "Social Entrepreneurship" and the formation of "B-Corporations" suggests that in the decades ahead, we will see business innovation aimed at social responsibility - at widening the social benefits of our economic system and reducing many of its costs. ${ }^{37}$ These developments support all three of the foundational convictions described earlier.

- "On the philanthropy front, there is recent evidence that even though recovery from the 2008 financial crisis is slow, corporate giving has rebounded." ${ }^{38}$ New efforts by multinational corporations to reduce poverty, pandemics, and corruption offer more reasons for hope as does the extraordinary work of the Bill and Melinda Gates Foundation and similar undertakings. ${ }^{39}$ 


\section{CONCLUSION}

As we look to the future, corporations seeking to preserve the trust and faith of society must embrace decision-making responsibility meaningfully. As our historical narrative insists in its final chapter, "the future of the corporation is tethered to the future of its responsible management." ${ }^{0}$ Businesses must address the issues that currently present themselves, such as the need for sustainability in the provision of all goods and services:

For if companies do not steadfastly embrace the project of corporate responsibility, other institutions will, and that may lead to the end of the most promising form of political economy for creating economic growth: free enterprise. ${ }^{41}$

The message of this article has been that, over the past two centuries, Americans have displayed significant tenacity in the pursuit of corporate responsibility and that this tenacity has been grounded in three foundational convictions-about checks \& balances, moral projection, and moral common ground. Our future grasp on this ideal for business as an institution depends profoundly on whether these foundational convictions are maintained and cultivated during the centuries that lie ahead. Let me conclude this article with the closing lines of our history:

The freedom of free markets, like the freedom of free persons, is a precious asset so long as society does not pay too high a price ... For [Adam] Smith, the true "wealth of nations" could only be realized if its citizens cultivated their moral sentiments as a foundation for their commercial enterprises. The future of corporate responsibility in the American experience depends, ultimately, on the choices of Americans themselves. ${ }^{42}$

\section{NOTES}

1. Special thanks and recognition are due to my Research Associate, Pati Provinske, for her many contributions to this essay-thorough research, careful editing, creative suggestions on style and graphics, and detailed citation and reference work. 
2. Throughout this paper, as in the history project, I used "corporate responsibility" as an umbrella phrase for a number of different identifiers that, while not synonymous, overlap considerably: business ethics, corporate social responsibility (CSR), corporate citizenship, corporate community involvement, stakeholder management, sustainability, and many more.

3. So much so that at one point, I considered proposing Tenacity as the title of our book instead of Corporate Responsibility: The American Experience (hereinafter, CRAE).

4. (Carroll, Lipartito, Post, Werhane, and Goodpaster, Executive Editor, 2012, 43-44). One recent controversial Supreme Court case illustrates the opposite side of the coin when it comes to attributing responsibilities to corporations, that is, what about corporations having rights? CRAE continues “. . . in 2010, the Supreme Court in Citizens United ruled that corporations (both for-profit and nonprofit) and unions could contribute freely to political campaign advocacy 'so long as they do not coordinate their efforts with campaigns or political parties' (OMB Watch 2010). The reasoning behind this decision, following an earlier 1906 decision, was that the corporation was an 'association of [natural] citizens,' and thus like individual natural citizens could freely participate in political campaign advocacy." See Citizens United v. Fed. Election Comm'n, 130 S. Ct. 876 (2010) and Johnson (2011, 2-6), for more on the "association of [natural citizens]."

5. (Carroll et al. 2012, Introduction, 15, 415).

6. (Novak 1982).

7. (Drucker 1994, 53-80).

8. (Rifkin 1996, 44-45).

9. (Tocqueville et al. 1945).

10. "The origins of American industrialization and private enterprise and the division between the public and private sectors, as shown in this chapter, are all grounded in a substantive theory of human rights. Also critical to the story are the importance of labor, the labor theory of value, which translates into the work ethic explained by Weber. At the same time there is the ongoing presence and third 'voice' of the public square so keenly observed and articulated by de Tocqueville" (Carroll et al. 2012, 61).

11. (Novak 1982, 56).

12. "The inarticulate practical wisdom embedded in the political system and in the moral-cultural system has profoundly affected the workings of the economic system" (Novak 1982, 56). It should be acknowledged that not all interventions into the economic sector by the other two 
sectors have been improvements. There has been much debate recently, for example, about the role of Fannie Mae in the home mortgage crisis.

13. (Novak 1982, 57).

14. This list could be greatly expanded: from the Ludlow Massacre and the Italian Hall Disaster (1913) to the National Labor Relations Act (1935) and the Taft-Hartley Act (1947); from the utopian business communities in the post-Civil War period to the company towns of the late nineteenth century to employee stock ownership plans in the 1920s to more robust employee benefits in the last third of the twentieth century; from the National Consumers League (1898) to the Better Business Bureau (1912) and the Federal Trade Commission (1914) to the Consumer Product Safety Commission (1972); from the creation of the Food and Drug Administration (1906) to the Environmental Protection Agency (1970); from the Federal Reserve System (1914) to the creation of the Securities Exchange Commission (1933) to the passage of the Dodd-Frank Act (2010); from discrimination against immigrants and the trade wars that often accompanied global competition, to the North American Free Trade Agreement (NAFTA, 1994) and the General Agreement on Tariffs and Trade (GATT, 1995).

15. The caption continues and appears as follows: This cartoon depicts President Theodore Roosevelt chastising two men- "Dishonest Corporations" (left) and "Union Tyranny" (second from left, with "Bribe" and "Graft" extending from his pockets)—who are trampling "Law" (the female figure) (Carroll et al. 2012, Plate 27).

16. In a later book, Novak makes this point even more clearly: "The fundamental reason behind the capacity for self-reform in democratic capitalism lies in the independence of its moral-cultural order and its political order alike. Both operate effectively upon its economic system. Each of these three systems represents a different aspect of reality, and each of them is moved by certain organic laws that, when violated, exact considerable costs. Thus the system as a whole comes under three quite different reality checks. This tension places the system regularly in crisis, each becoming an opportunity for fresh restructuring” $(1993,58)$.

17. (Drucker 1978, Eastern edition, 12).

18. "By 1914 almost 80 percent of workers were employed by corporations, who produced 80 percent of the value of manufactured goods" (Carroll et al. 2012, 118; US Census Bureau 1920; Ripley 1929). In 2002, in his book, Organizing America: Wealth, Power, and the Origins of Corporate Capitalism, Charles Perrow wrote about the percentage of people working in organizations: "In 1820, about 20 percent of the population 
worked for wages and salaries; by 1900 it was 50 percent; today it is well over 90 percent ...” (227).

19. I formalized this analogical perspective in an article with John Matthews in the Harvard Business Review, "Can a Corporation Have a Conscience?" (January 1982) and eventually labeled it the "Principle of Moral Projection" (Goodpaster 2005, 363-364).

20. "This landmark decision gave corporate bodies, those chartered, or, later, incorporated, the same rights as individuals to buy, sell, own, and disperse property. The decision was qualified in the conclusion with the statement that '[a] corporation is an artificial being, invisible, intangible, and existing only in the contemplation of law"' (Carroll et al. 2012, 43; Trustees of Dartmouth College v. Woodward, 17 U.S. at 636, quoted in Johnson 2011, 5).

21. Lyman Johnson, in his commissioned essay for the CRAE history project, observed: "After all, it is corporate responsibility that has emerged as a topic of ongoing social concern and scholarly study. This required that the corporation be recognized as a meaningful social and legal actor, distinguishable from its constituents" (12).

22. In her article, "Ethics without the Sermon," Laura L. Nash discusses "twelve questions to ask when making a business decision" and the process involved in reviewing them (1981, 88-89).

23. Johnson adds: "Conversely, this very legal discretion leads many to doubt that such freedom will be used responsibly. It is to constrain corporate conduct-not unleash it-that historically has led these persons to advocate corporate regulation of various kinds" (2011, 31).

24. See Philip Selznick, Leadership in Administration: A Sociological Interpretation: "As an organization acquires a self, a distinctive identity, it becomes an institution. This involves the taking on of values, ways of acting and believing that are deemed important for their own sake. From then on, self-maintenance becomes more than bare organizational survival; it becomes a struggle to preserve the uniqueness of the group in the face of new problems and altered circumstances" [emphasis mine] (1957, 21). Also, see Hugh Heclo's book, On Thinking Institutionally (2008).

25. This passage continues: "This individualization of the meaning of 'conscience' . . . signals a polarity at the core of our moral awareness: On the one hand, conscience is our subjective touchstone for ethical decision making. On the other hand, an appeal to conscience in moral argument (or dialogue) usually lays claim to common ground, a warrant for our ethical convictions that reaches beyond the merely subjective. Insofar as conscience must respond in actual decision making 
situations, it has a certain private authority, both in relation to nonmoral decision guides and in relation to the consciences of others. We can refer to this as the autonomy dimension of conscience. But because conscience can be 'undeveloped,' 'neglected,' or 'out of touch,' philosophers have looked to it for a broader kind of authority, less private and more rooted in human nature or reason. We can refer to this as the discernment dimension of conscience" (Goodpaster 2008, 407-408).

26. (Brooks 2011).

27. See Goodpaster's “Goods That Are Truly Good and Services That Truly Serve: Reflections on "Caritas in Veritate" in the Journal of Business Ethics (2011).

28. Professor John B. Matthews, my mentor at Harvard Business School, wrote a classic case study, "Tennessee Coal and Iron," in which President John F. Kennedy implored Mr. Arthur Wiebel, COO of a division of US Steel Corporation in Birmingham, Alabama, to take initiatives in his company's workplace to advance civil rights, to be a power of example to other firms by embracing the spirit, not just the letter, of the laws (1963, 233).

29. Insight into this process of discovering our moral common ground was evident nearly 100 years ago, when University of Chicago economist J. M. Clark called for an "economics of responsibility" from business practitioners: "The ideas of obligation which embody the actual relations of man to man in the [twentieth] century are radically different from the ideas which dominated the nineteenth . . . Some have failed to recognize what the change means and have resisted it uncomprehendingly . . . Some have gone to the other extreme and have lost their old sense of personal accountability . . . [But] many . . . are honestly seeking to know what their obligations are in this new era, that they may meet them on their own initiative. More knowledge is wanted, that men may guide themselves. The modern prayer is not so much for strength as for wisdom . . . [We] need something more; something which is still in its infancy. We need an economics of responsibility, developed and embodied in our working business ethics [emphasis added]" (Clark 1916, 209-229, in Carroll et al. 2012, 13).

30. I have argued recently, however, that the emergence of stakeholder thinking, while necessary, is not sufficient in our quest for corporate responsibility. See Goodpaster's "Business Ethics: Two Moral Provisos” in Business Ethics Quarterly (2010, 740-742).

31. Lee Kwan Yew, Singapore, was a critic of US emphasis on individual civil liberties (Zakaria 1994, 109-126). 
32. "If the skimpy existent mechanisms of corporate governance cannot themselves accommodate a modern society's evolving expectations of corporate power-whether control lies in investor or manager hands, or is held jointly-then it is to be expected that renewed efforts to bring non-investor voices (and concerns) into corporate governance will begin again, or that even more extensive legal regulation addressing various kinds of such interests will be forthcoming. Nowhere is it clearer than in the very heart of the corporation-i.e., the corporate governance realm-that law plays a central role in the story of corporate responsibility" (Johnson 2011, 27).

33. (Hicks 2011, 852-854).

34. An Ethics Resource Center Report provides this example by R. E. Berenbeim: "The specifics of the Guidelines aside, the most important story that emerges from the FSGO's 20 year history is that the USSC's carrot and stick approach has catalyzed vigorous efforts by companies to promote ethical performance and reduce organizational misconduct" (Ethics Resource Center 2012, 28; Berenbeim 2005). The Ethics Officers Association (EOA), now called the Ethics and Compliance Officers Association (ECOA), had its origin, of course, at Bentley University.

35. A group from the Class of 2009 Graduates of Harvard Business School, created the MBA Oath, "building upon these essential efforts [from the Hippocratic Oath to Thunderbird's Oath of Honor, and the Columbia Business School Honor Code] to create a community of MBAs with a high standard for ethical and professional behavior" (MBA Oath: Responsible Value Creation, n.d.).

36. In their article, "Management as a Profession?" Rakesh Khurana, Nitin Nohria, and Daniel Penrice state, "Our speculations about a genuine professionalization of management as a remedy for the crisis of legitimacy now facing American business may strike some as radical. But assuming, once again, that increased regulation is not the whole or the best answer to the problem at hand, we believe that our idea of making management into a bona fide profession has the virtue of asking a group that has seriously abused the public's trust to make a serious commitment to restoring it" (2005). Also see Michael Novak's book, Business as a Calling: Work and the Examined Life (1996); and the new Vatican document, the Vocation of the Business Leader: A Reflection, by the Pontifical Council for Justice and Peace (2012).

37. Regarding social entrepreneurship, a group of "hybrid companies and proprietorships that label themselves "social entrepreneurs"-include "individuals and organizations [that] may be not-for profit, public, for- 
profit, or hybrid ventures. What is distinctive . . . is that their core mission is to add value not merely monetarily, but also by making a positive social, cultural, or environmental impact" (Carroll et al. 2012, 392). Looking at the B-Corporation: "A new type of legally sanctioned corporation, the 'Benefit Corporation' or B-Corporation is taking shape. According to the organization's website, B-Corporation promotes the power of business to solve social and environmental problems" (Carroll et al. 2012, 393).

38. (Carroll et al. 2012, 422; CEPC 2011).

39. See Poverty through Profitable Partnerships: Globalization, Markets, and Economic Well-Being by Patricia Werhane, Scott Kelly, Laurab Hartman, and Dennis Moberg (2010); and Obstacles to Ethical Decision-Making: Mental Models, Milgram and the Problem of Obedience by Patricia Werhane, Laura Hartman, Crina Archer, Elain Englehardt, and Michael Pritchard (2013).

40. "This may be the only way to preserve the corporation as an institution under private direction for public benefit" (Carroll 2012, 423).

41. Emphasis added. (Carroll et al. 2012, 423).

42. (Carroll et al. 2012, 424).

\section{REFERENCES}

Berenbeim, R. E. 2005. "Universal conduct-An ethics and compliance benchmarking survey," The Conference Board, Research Report RR-1393-06. In "The federal sentencing guidelines for organizations at twenty years." Report of the Ethics Resource Center's Independent Advisory Group on the 20th Anniversary of FSGOI, 28. Ethics Resource Center. 2012, http://www.ethics.org/files/u5/fsgo-report2012.pdf, accessed January 30, 2013.

Brooks, D. 2011. "If it feels right ...," New York Times, September 12, http://www.nytimes.com/2011/09/13/opinion/if-it-feels-right.html ?_r=0, accessed January 25, 2013.

Carroll, A. B., Lipartito, K. J., Post, J. E., Werhane, P. H., and Goodpaster, K. E., Executive Editor. 2012. Corporate Responsibility: The American Experience. Cambridge: Cambridge University Press.

Citizens United v. Fed. Election Comm'n, 130 S. Ct. 876 (2010).

Clark, J. M. 1916. "The changing basis of economic responsibility," Journal of Political Economy 24(3): 209-229.

Committee Encouraging Corporate Philanthropy (CEPC). 2011. "Companies report increased philanthropic giving in 2010: CECP releases first look at changes from pre-economic crisis levels," Press Release, June 2, http://cecp.co/pdfs/press/cecppr/June2011_CGS_Press

_Release.pdf, accessed September 30, 2013. 
Declaration of Independence: A Transcription. 1776. "A new world is at hand," The Charters of Freedom. National Archives, http://www.archives .gov/exhibits/charters/declaration_transcript.html, accessed January 30, 2013.

Drucker, P. F. 1978. "We have become a society of organizations," Wall Street Journal, January 9, Eastern edition, 12.

Drucker, P. F. 1994. "The age of social transformation," Atlantic Monthly 274(5): 53-80, http://www.theatlantic.com/past/docs/issues/95dec/ chilearn/drucker.htm, accessed January 23, 2013.

Ethics Resource Center. 2012. "The federal sentencing guidelines for organizations at twenty years." Report of the Ethics Resource Center's Independent Advisory Group on the 20th Anniversary of FSGO, 28, http://www.ethics.org/files/u5/fsgo-report2012.pdf, accessed January 30, 2013.

Goodpaster, K. E. 2005. "Moral projection, principle of," in P. H. Werhane and R. E. Freeman, eds., The Blackwell Encyclopedia of Management, Business Ethics, Vol. 2, 2nd ed. Cary L. Cooper, Encyclopedia Editor. Malden, MA: Blackwell Publishing, pp. 363-364.

Goodpaster, K. E. 2008. "Conscience," in R. W. Kolb, ed., Encyclopedia of Business Ethics and Society, Vol. 1. Thousand Oaks, CA: SAGE, pp. 407-410.

Goodpaster, K. E. 2010. "Business ethics: Two moral provisos," Business Ethics Quarterly 20(4): 740-742.

Goodpaster, K. E. 2011. "Goods that are truly good and services that truly serve: Reflections on 'Caritas in Veritate," Journal of Business Ethics 100(1): 9-16, Supplement.

Goodpaster, K. E., and Matthews, J. B., Jr. 1982. "Can a corporation have a conscience?" Harvard Business Review 60(1): 132-141.

Heclo, H. 2008. On Thinking Institutionally. Boulder, CO: Paradigm Publishers.

Hicks, S. R. C. (2011-07-16). Explaining Postmodernism: Skepticism and Socialism from Rousseau to Foucault. Roscoe, IL: Ockham's Razor Publishing. Kindle Edition.

Johnson, L. 2011. "Law and the history of corporate responsibility," CEBC History of Corporate Responsibility Project Working Paper No. 6. Minneapolis, MN: Center for Ethical Business Cultures at the Opus College of Business, University of St. Thomas, http:// www.cebcglobal.org/uploaded_files/Corporate_Law_and_History_of _CR_-_Johnson_working_paper_-_final.pdf, accessed September 30, 2013.

Khurana, R., Nohria, N., and Penrice, D. 2005. "Is business management a profession?" Harvard Business School Working Paper, February 21, http://hbswk.hbs.edu/item/4650.html, accessed January 29, 2013. Also, reprinted as "Management as a profession" from Restoring Trust in American Business, edited by Jay W. Lorsch, Leslie Berlowitz, and Andy Zelleke. Cambridge, MA: American Academy of Arts and Sciences: MIT Press. 
Matthews, J. B. 1963. "Tennessee coal and iron," Case Study, in M. W. Hoffman, R. Frederick, and M. S. Schwartz, eds., 2001, Business Ethics: Readings and Cases in Corporate Morality. New York: McGraw Hill, pp. 233-241.

MBA Oath: Responsible Value Creation. n.d. "MBA oath," http:// mbaoath.org, accessed February 8, 2013.

Nash, L. L. 1981. "Ethics without the sermon," Harvard Business Review 59(6): 78-90.

Novak, M. 1982. The Spirit of Democratic Capitalism. New York: Simon and Schuster.

Novak, M. 1993. The Catholic Ethic and the Spirit of Capitalism. New York: Free Press.

Novak, M. 1996. Business as a Calling: Work and the Examined Life. New York: Free Press.

OMB Watch. 2010. "Citizens united: The supreme court decision and its potential impacts," January 27. Katherine McFate, Executive Director, http://www.foreffectivegov.org/node/10722/Citizens-United-The -Supreme-Court-Decision-and-Its-Potential-, accessed August 9, 2010.

Perrow, C. 2002. Organizing America: Wealth, Power, and the Origins of Corporate Capitalism. Princeton, NJ: Princeton University Press.

Pontifical Council for Justice and Peace. 2012. Vocation of the Business Leader: A Reflection. Vatican City: Pontifical Council for Justice and Peace, http://www.stthomas.edu/cathstudies/cst/VocationBusiness Lead, accessed January 25, 2013.

Rifkin, J. 1996. "Rethinking the mission of American education: Preparing the next generation for the civil society," Education Week 15(19): 44-45.

Ripley, W. Z. 1929. Main Street and Wall Street. Boston, MA: Little, Brown.

Selznick, P. 1957. Leadership in Administration: A Sociological Interpretation. New York: Harper \& Row.

Tocqueville, A. D., Bradley, P., Reeve, H., and Bowen, F. 1945. Democracy in America. New York: A. A. Knopf.

Trustees of Dartmouth College v. Woodward, 17 U.S. 518 (1819).

US Census Bureau. 1920. "Census of population and housing: 1920 census,” Volume 8. Manufacturers, 1919. General Report and Analytical Tables.

Werhane, P. H., Hartman, L. P., Archer, C., Englehardt, E. E., and Pritchard, M. S. 2013. Obstacles to Ethical Decision-Making: Mental Models, Milgram and the Problem of Obedience. New York: Cambridge University Press.

Werhane, P. H., Kelly, S., Hartman, L., and Moberg, D. 2010. Alleviating Poverty Through Profitable Partnerships: Globalization, Markets and Economic Well-Being. New York: Routledge.

Zakaria, F. 1994. "Culture is destiny: A conversation with Lee Kuan Yew," Foreign Affairs 73(2): 109-126. 